\title{
Synergy between DNA polymerases increases polymerase chain reaction inhibitor tolerance in forensic DNA analysis
}

\author{
Johannes Hedman a,b, Anders Nordgaard ${ }^{\text {b,c }}$, Charlotte Dufva ${ }^{\mathrm{b}}$, Birgitta Rasmusson ${ }^{\mathrm{b}}$, Ricky Ansell ${ }^{\mathrm{b}, \mathrm{d}}$, \\ Peter Rådström ${ }^{\mathrm{a} \text {,* }}$
}

${ }^{a}$ Department of Applied Microbiology, Lund University, SE-221 00 Lund, Sweden

${ }^{\mathrm{b}}$ Swedish National Laboratory of Forensic Science (SKL), SE-581 94 Linköping, Sweden

${ }^{\mathrm{c}}$ Department of Computer and Information Science, Linköping University, SE-581 83 Linköping, Sweden

${ }^{\mathrm{d}}$ Department of Physics, Chemistry, and Biology, Linköping University, SE-581 83 Linköping, Sweden

\section{A R T I C L E I N F O}

\section{Article history:}

Received 29 March 2010

Received in revised form 13 June 2010

Accepted 14 June 2010

Available online 19 June 2010

\section{Keywords:}

DNA polymerase

DNA polymerase blend

Forensic DNA analysis

PCR inhibition

PCR inhibitors

Synergy

\begin{abstract}
A B S T R A C T
The success rate of diagnostic polymerase chain reaction (PCR) analysis is lowered by inhibitory substances present in the samples. Recently, we showed that tolerance to PCR inhibitors in crime scene saliva stains can be improved by replacing the standard DNA polymerase AmpliTaq Gold with alternative DNA polymerase-buffer systems (Hedman et al., BioTechniques 47 (2009) 951-958). Here we show that blending inhibitor-resistant DNA polymerase-buffer systems further increases the success rate of PCR for various types of real crime scene samples showing inhibition. For 34 of 42 "inhibited" crime scene stains, the DNA profile quality was significantly improved using a DNA polymerase blend of ExTaq Hot Start and PicoMaxx High Fidelity compared with AmpliTaq Gold. The significance of the results was confirmed by analysis of variance. The blend performed as well as, or better than, the alternative DNA polymerases used separately for all tested sample types. When used separately, the performance of the DNA polymerases varied depending on the nature of the sample. The superiority of the blend is discussed in terms of complementary effects and synergy between the DNA polymerase-buffer systems.
\end{abstract}

(c) 2010 Elsevier Inc. All rights reserved.
The polymerase chain reaction $(\mathrm{PCR})^{1}$ is a powerful tool for quick analysis of minute DNA amounts [1]. However, the success rate of diagnostic PCR analysis is lowered by the presence of PCRinhibitory substances [2], a problem especially prominent in forensic DNA analysis due to the often complex sampling environment at crime scenes [3-5]. Recently, we reported that $12 \%$ of volume crime saliva stains with adequate DNA amounts analyzed at our laboratory still produced negative DNA profiles due to the presence of inhibitors [6]. Failure to generate acceptable DNA profiles can have severe effects; for example, it can lead to cases being left unsolved or to wrongly accused people not being exculpated.

AmpliTaq Gold has been the standard thermostable DNA polymerase for forensic DNA analysis worldwide since the advent of commercial DNA typing kits such as AmpFlSTR SGM Plus (Applied Biosystems, Foster City, CA, USA) and PowerPlex-16 (Promega,

\footnotetext{
* Corresponding author. Fax: +46 462224203.

E-mail address: peter.radstrom@tmb.lth.se (P. Rådström).

1 Abbreviations used: PCR, polymerase chain reaction; STR, short tandem repeat; PET, polyethylene terephthalate; IPC, internal PCR control; dNTP, deoxynucleoside triphosphate; BSA, bovine serum albumin; CE, capillary electrophoresis; FI, forensic DNA profile index; TPH, total peak height; RFU, relative fluorescence units; MLB, mean local balance; SH, Shannon entropy; Flgm, geometric mean of FI; LSR, least significant ratio.
}

Madison, WI, USA). It is also an integrated part of the new AmpFlSTR NGM kit (Applied Biosystems). However, AmpliTaq Gold might not be the optimal choice for samples containing PCR inhibitors. In several studies, AmpliTaq Gold has shown lower tolerance to PCR-inhibitory substances compared with other DNA polymerases [7-11]. We have previously shown that short tandem repeat (STR) DNA analysis of complex crime scene samples can be improved by replacing AmpliTaq Gold with either of the alternative DNA polymerase-buffer systems Bio-X-Act Short (Bioline, London, UK), ExTaq Hot Start (TaKaRa Bio, Shiga, Japan), or PicoMaxx High Fidelity (Stratagene, La Jolla, CA, USA) [6].

ExTaq Hot Start and PicoMaxx High Fidelity showed complementary abilities to amplify DNA in the presence of the various sample types tested; that is, one was more resistant to certain substances and vice versa. Theoretically, a blend of complementary DNA polymerases would provide inhibitor-tolerant amplification for a wider range of disturbing substances compared with either system used separately. In this study, we blended two alternative DNA polymerase-buffer systems and tested the performance of the blend on various real crime scene samples showing inhibition such as cigarette butts, chewing gum, and swabs from aluminum cans. Moreover, we investigated the possibility of synergy between the two systems, that is, whether the inhibitor tolerance of the 
blend is increased compared with either of the included DNA polymerases used separately.

\section{Materials and methods}

\section{Samples}

The DNA polymerase-buffer systems were evaluated using both pure 007 Standard DNA (0.1 ng/ $\mu$ l, Applied Biosystems) and real crime scene DNA extracts showing PCR inhibition. In total, 15 replicates of pure DNA were analyzed using AmpliTaq Gold (2.5 U), and 10 replicates were analyzed using each of the four alternative DNA polymerase-buffer systems. In addition, 42 problematic DNA extracts were selected from routine crime scene samples analyzed at the Swedish National Laboratory of Forensic Science (SKL, Linköping, Sweden). The DNA concentrations in the selected samples were above the manufacturer's recommended limit for successful analysis (AmpFISTR SGM Plus PCR Amplification Kit user's manual), ranging from 0.05 to $0.22 \mathrm{ng} / \mu \mathrm{l}$, but they all had failed to produce complete DNA profiles using AmpliTaq Gold and the AmpFISTR SGM Plus kit due to the presence of PCR-inhibitory substances. In total, 16 of the DNA extracts emanated from cigarette butts, 11 emanated from cotton swabs (SelefaTrade, Spånga, Sweden) (6 from aluminum cans, 3 from polyethylene terephthalate [PET] bottles, and 2 from foodstuffs), 10 emanated from moist snuff, and 5 emanated from chewing gum. For most samples, DNA extraction was performed using Chelex beads (Bio-Rad Laboratories, Hercules, CA, USA) [12], with the addition of Centricon purification (Millipore, Billerica, MA, USA) [13] for visibly dirty samples. Phenolchloroform purification [14] was used on especially complicated samples. A complete list of which DNA extraction/purification method was used for each sample is provided in Table S2 of the Supplementary material. DNA quantification was performed using the Quantifiler Human kit (Quantifiler kit user's manual) on an ABI 7300 (Applied Biosystems). The Quantifiler kit includes an internal PCR control (IPC) for estimation of PCR inhibition. However, the IPC only flagged for inhibition in 14 of the 42 crime scene stains that were clearly inhibited in standard AmpFISTR SGM Plus analysis (results not shown), strengthening the notion that the multiplex STR analysis is more sensitive to inhibitors than the Quantifiler assay [6].

\section{Multiplex STR analysis}

The AmpFlSTR SGM Plus kit (Applied Biosystems) was used as a base for all analyses. Multiplex STR analysis was performed using the following DNA polymerase-buffer systems: AmpliTaq Gold (2.5 U [standard] or $5 \mathrm{U}$ per reaction, modified Taq with hot start capability), ExTaq Hot Start (2.5 U per reaction, modified Taq with hot start capability) $[15,16]$, PicoMaxx High Fidelity (2.5 U per reaction, a mixture of recombinant Taq and cloned Pfu polymerase, polymerases with hot start capability, also including a polymeraseenhancing factor protein) [17-20], and a 1:1 blend of the ExTaq Hot Start and PicoMaxx High Fidelity master mixes (2.5 U per reaction in total, $1.25 \mathrm{U}$ of each DNA polymerase). The AmpFISTR SGM Plus PCR master mix with AmpliTaq Gold was prepared following the manufacturer's guidelines (AmpFlSTR SGM Plus PCR Amplification Kit user's manual). For $5 \mathrm{U}$ of AmpliTaq Gold reactions, $1 \mu \mathrm{l}$ of AmpliTaq Gold DNA polymerase per reaction was added to the master mix. For ExTaq Hot Start and PicoMaxx High Fidelity, reaction master mixes were prepared using $2.5 \mathrm{U}$ of polymerase, $1 \times$ polymerase-specific PCR buffer (ExTaq buffer or PicoMaxx reaction buffer), $0.2 \mathrm{mM}$ deoxynucleoside triphosphate (dNTP), $0.25 \mu \mathrm{g} / \mu \mathrm{l}$ bovine serum albumin (BSA), and $5.5 \mu \mathrm{l}$ of AmpFISTR SGM Plus primer mix (Applied Biosystems). Pure Milli-Q water was added to a final master mix volume of $16.5 \mu \mathrm{l}$. When preparing the ExTaq Hot Start/PicoMaxx High Fidelity blend, equal amounts of master mix from the two DNA polymerase-buffer systems were used. For all analyses, $15 \mu \mathrm{l}$ of the final master mix was dispensed into PCR plate wells together with $10 \mu \mathrm{l}$ of DNA template, giving a $25-\mu \mathrm{l}$ reaction volume. All crime scene stain analyses were performed in duplicates. Thermal cycling was performed using the recommended PCR program (AmpFlSTR SGM Plus PCR Amplification Kit user's manual) on a GeneAmp PCR System 9700 (Applied Biosystems). A 3130xl Genetic Analyzer (Applied Biosystems) was used for fragment separation, and capillary electrophoresis (CE) data were analyzed using GeneMapper ID software (version 3.1, Applied Biosystems).

\section{Comparison of DNA profile quality using FI}

The previously described forensic DNA profile index (FI) $[6,21]$ was used to quantify the quality differences between DNA profiles generated by the different DNA polymerase-buffer systems. In short, the FI uses principal components analysis to create one single value describing the quality of an electropherogram/DNA profile based on three measures: (i) the total peak height (TPH) of the CE electropherogram, that is, the sum of the heights of all true allelic STR peaks observed in a DNA profile given in relative fluorescence units (RFU); (ii) the mean local balance (MLB, intralocus balance), that is, the mean of ratios between the two peaks within each heterozygous STR locus in an electropherogram; and (iii) the Shannon entropy ( $\mathrm{SH}$, interloci balance), that is, discrepancies between the sums of the peak heights of the different STR markers in an electropherogram. The FI values from analysis with the alternative DNA polymerase setups were compared with those obtained from standard AmpliTaq Gold analysis (2.5 U) of the same extract. The performance of the blend was also compared with each of the included DNA polymerase-buffer systems used separately. The pairwise comparison procedure used is described below.

The FI is assumed to have a lognormal probability distribution such that

$\operatorname{In}\left(\mathrm{FI}_{i j}\right) \sim N\left(\mu_{i}, \sigma\right)$

for observed sample $j$ analyzed with DNA polymerase-buffer system $i$, where $\mu_{i}$ is the mean value obtained using DNA polymerase $i$ and $\sigma$ is the measurement standard deviation common to all samples (irrespective of the DNA polymerase used). Ordinary pairwise comparisons of sample arithmetic means from analyses using different DNA polymerase-buffer systems are then replaced by comparisons of sample geometric means of the FI (FIgm), comparing the pairwise ratios of geometric means with a least significant ratio (LSR) computed as

$L S R=e^{z \cdot \tilde{\sigma} \cdot \sqrt{\frac{1}{n_{1}}+\frac{1}{n_{2}}}}$

where $\tilde{\sigma}$ is a stable estimate of $\sigma$ from a calibration set of measurements [6], $z$ is the appropriate quantile of the normal distribution based on the number of comparisons made to reach the final conclusion (based on the family level of significance), and $n_{1}$ and $n_{2}$ are the numbers of replicate values for each DNA polymerase-buffer system. If the FIgm ratio surpasses the LSR for a certain sample, there is a significant difference in quality between the DNA profiles generated by the two DNA polymerase-buffer systems.

Here LSR was calculated based on a $10 \%$ significance level. For pure DNA, 10 replicates were analyzed using the alternative DNA polymerases and 15 were analyzed using AmpliTaq Gold, generating an LSR of 1.22 for a single comparison of one DNA polymerase with the standard. For comparisons between alternative DNA polymerases (10 replicates each), LSR became 1.24 . For the real crime scene 
samples, two replicates were analyzed for each DNA polymerasebuffer system, giving an LSR of 1.62 for single comparisons.

The assumption that obtained FI values follow a lognormal distribution (i.e., that the logarithms of the FI show a constant error variance irrespective of the DNA polymerase and DNA sample) is based on the results from a calibration study [21]. The error variance shows stability and the obtained FI values show a rightskewed distribution that becomes symmetric when the natural logarithm is applied. However, no thorough investigation of other properties of this distribution, such as concordances with respect to properties of skewness and kurtosis, has been performed. The approximation of lognormality seems to be valid and does not violate achieved significances. This is supported in particular by the relatively modest level of significance (10\%).

\section{Results}

\section{STR analysis of pure DNA}

When pure DNA was analyzed, all tested DNA polymerase-buffer systems produced complete, well-balanced DNA profiles with peak heights well above the detection limit for all analyses (see Table S1 in Supplementary material for a complete list of results). Only true allelic peaks and no problematic erroneous peaks were generated. The FI was used to quantify the quality of the generated electropherograms/DNA profiles [6]. Quality comparisons between the tested systems were performed by calculating and comparing FIgm values for the replicate analyses of pure DNA. The ExTaq Hot Start/PicoMaxx High Fidelity blend produced DNA profiles of significantly higher quality compared with standard AmpliTaq Gold ( $2.5 \mathrm{U}$ ), as confirmed by their respective FIgm values of 9.62 and 7.11 (FIgm ratio $=1.35$, LSR $=1.22,10 \%$ significance level). PicoMaxx High Fidelity produced an FIgm value of 8.16, ExTaq Hot Start produced a value of 7.09, and AmpliTaq Gold (5 U) produced a value of 7.77, all generating DNA profiles of indistinguishable quality compared with AmpliTaq Gold (2.5 U). The only significant difference between the alternative DNA polymerasebuffer systems themselves was between the blend and ExTaq Hot Start $($ FIgm ratio $=1.36$, LSR $=1.24,10 \%$ significance level $)$.

\section{STR analysis of crime scene saliva samples showing inhibition}

The ExTaq Hot Start/PicoMaxx High Fidelity blend significantly improved the DNA profiles for 34 of 42 crime scene samples showing inhibition compared with AmpliTaq Gold (FIgm ratios over LSR $=1.62,10 \%$ significance level) (Table 1 ). Using AmpliTaq Gold, 18 of the tested stains generated negative/blank DNA profiles or profiles with only one visible STR marker (FIgm from 0.05 to 0.13). For 16 of these, the blend generated complete DNA profiles with peak heights well above the detection limit (FIgm values from 1.2 to 13.1 ). The remaining 2 were significantly improved, although they produced partial DNA profiles (FIgm values $=0.65$ and 0.87 ) (Table 2 and Table S2 in Supplementary material).

ExTaq Hot Start and PicoMaxx High Fidelity used separately both performed considerably better than AmpliTaq Gold in total but showed complementary abilities to retain activity for different sample types (Figs. 1-4 and Table 1). For the 5 cigarette butts with the highest inhibitory effect on AmpliTaq Gold, generating negative/ blank DNA profiles, ExTaq Hot Start also failed completely. For the same samples, PicoMaxx High Fidelity produced 3 complete DNA profiles (FIgm values from 1.09 to 3.01 ) and 2 partial DNA profiles $($ FIgm values $=0.21$ and 0.27$)$ (see Table S2, samples 4, 10, 13, 14, and 16). However, for 5 of the 10 moist snuff samples, AmpliTaq Gold produced DNA profiles of significantly higher quality compared with PicoMaxx High Fidelity (FIgm ratios from 2.26 to 9.63 , $\mathrm{LSR}=1.62$, $10 \%$ significance level), whereas the remaining 5 were indistinguishable. ExTaq Hot Start generated 10 nearly or totally complete DNA profiles (FIgm values from 0.94 to 15.54), all of which were of significantly higher quality compared with PicoMaxx High Fidelity (FIgm ratios from 1.63 to 31.14 , $L S R=1.62,10 \%$ significance level). The complementary effects of the systems were verified by the fact that, for all tested samples irrespective of sample type, the blend performed at least as well as the enzyme with the best performance of the two (Table 2 and Table S2).

In addition to complementary effects, the results indicated synergy between ExTaq Hot Start and PicoMaxx High Fidelity. For 6 especially complicated samples ( 3 cigarette butts, 1 swab from a PET bottle, 1 moist snuff sample, and 1 chewing gum sample), the blend produced DNA profiles of significantly higher quality compared with either of the two DNA polymerase-buffer systems used separately (FIgm ratios from 1.90 to 41.79 , LSR $=1.62,10 \%$ significance level) (see Figs. 1 and 3, Table 2, and Table S2, samples $8,13,16,25,32$, and 40 ). There was no case where a single alternative DNA polymerase performed significantly better than the blend.

\section{Discussion}

The design and use of DNA polymerase blends is an ingenious way of adding specific desirable properties to the PCR. Typically, a polymerase with 3' exonuclease activity is added to a Taq-mediated PCR, thereby increasing fidelity and enabling amplification of longer fragments [22-24]. Here we show that PCR inhibitor tolerance can be improved by blending two DNA polymerase-buffer systems. For analysis of "inhibited" real crime scene samples from various sources, the ExTaq Hot Start/PicoMaxx High Fidelity blend outperformed the standard AmpliTaq Gold DNA polymerase as well as either ExTaq Hot Start or PicoMaxx High Fidelity used separately.

It is well known that different DNA polymerases have different abilities to retain polymerizing activity in various complex reaction environments, explained either by their different origins [7-10] or

Table 1

Improved DNA amplification of crime scene samples using alternative DNA polymerase-buffer systems.

\begin{tabular}{|c|c|c|c|c|c|c|c|}
\hline DNA polymerase-buffer system & $\begin{array}{l}\text { Chewing gum } \\
(n=5)\end{array}$ & $\begin{array}{l}\text { Cigarette butts } \\
(n=16)\end{array}$ & $\begin{array}{l}\text { Moist snuff } \\
(n=10)\end{array}$ & $\begin{array}{l}\text { Swabs (aluminum cans) } \\
(n=6)\end{array}$ & $\begin{array}{l}\text { Swabs (food) } \\
(n=2)\end{array}$ & $\begin{array}{l}\text { Swabs (PET bottles) } \\
(n=3)\end{array}$ & $\begin{array}{l}\text { Total } \\
(N=42)\end{array}$ \\
\hline AmpliTaq Gold (5 U) & $1 / 5$ & $5 / 16$ & $7 / 10$ & $3 / 6$ & $1 / 2$ & $0 / 3$ & $18 / 42$ \\
\hline ExTaq Hot Start (2.5 U) & $3 / 5$ & $10 / 16$ & $8 / 10$ & $4 / 6$ & $1 / 2$ & $0 / 3$ & $27 / 42$ \\
\hline PicoMaxx High Fidelity (2.5 U) & $5 / 5$ & $14 / 16$ & $0 / 10$ & $4 / 6$ & $0 / 2$ & $0 / 3$ & $23 / 42$ \\
\hline $\begin{array}{l}\text { Blend, ExTaq Hot Start/PicoMaxx } \\
\text { High Fidelity }(2.5 \mathrm{U})\end{array}$ & $5 / 5$ & $15 / 16$ & $9 / 10$ & $4 / 6$ & $1 / 2$ & $0 / 3$ & $34 / 42$ \\
\hline
\end{tabular}

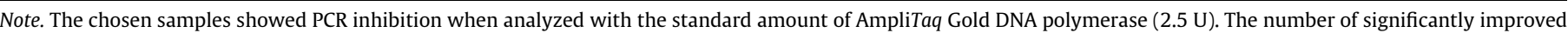

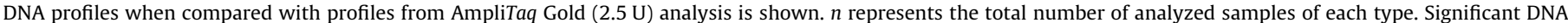

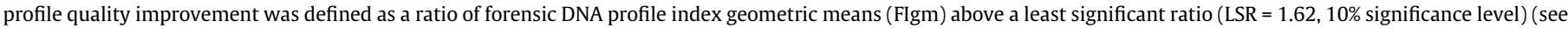
Materials and methods). 
Table 2

Results from DNA analysis of four typical crime scene samples showing PCR inhibition.

\begin{tabular}{|c|c|c|c|c|c|c|c|c|c|c|c|c|}
\hline $\begin{array}{l}\text { Sample } \\
\text { number }\end{array}$ & Sample type & $\begin{array}{l}\text { DNA } \\
\text { extraction } \\
\text { method }\end{array}$ & $\begin{array}{l}\text { DNA } \\
\text { conc. } \\
(\mathrm{ng} / \mu \mathrm{l})\end{array}$ & DNA polymerase & TPH & $\mathrm{MLB}^{\mathrm{a}}$ & $\mathrm{SH}^{\mathrm{a}}$ & $\mathrm{FI}^{\mathrm{a}}$ & Flgm & $\begin{array}{l}\text { Ratio of Flgm } \\
\text { for alternative } \\
\text { DNA polymerase } \\
\text { to Flgm for } \\
\text { AmpliTaq Gold } \\
(2.5 \mathrm{U})\end{array}$ & $\begin{array}{l}\text { Significant } \\
\text { improvement } \\
(\text { ratio }>\text { LSR }=1.62)\end{array}$ & $\begin{array}{l}\text { Number o } \\
\text { STR } \\
\text { markers } \\
\text { with } \\
\text { true allelic } \\
\text { peaks }>50 \\
\text { RFU }(0-10)\end{array}$ \\
\hline \multirow[t]{10}{*}{8} & \multirow[t]{10}{*}{ Cigarette butt } & \multirow[t]{10}{*}{ Chelex } & \multirow[t]{10}{*}{0.22} & \multirow[t]{2}{*}{ AmpliTaq Gold (2.5 U) } & 68 & 0.47 & 0.00 & 0.06 & \multirow[t]{2}{*}{0.06} & \multirow[t]{2}{*}{ - } & \multirow[t]{2}{*}{-} & 1 \\
\hline & & & & & 165 & 0.47 & 0.00 & 0.07 & & & & 1 \\
\hline & & & & \multirow[t]{2}{*}{ AmpliTaq Gold (5 U) } & 386 & 0.47 & 0.51 & 0.22 & \multirow[t]{2}{*}{0.58} & \multirow[t]{2}{*}{9.07} & \multirow[t]{2}{*}{ Yes } & 1 \\
\hline & & & & & 8305 & 0.63 & 1.50 & 1.54 & & & & 6 \\
\hline & & & & \multirow[t]{2}{*}{ ExTaq Hot Start (2.5 U) } & 706 & 0.47 & 0.00 & 0.14 & \multirow[t]{2}{*}{0.21} & \multirow[t]{2}{*}{3.28} & \multirow[t]{2}{*}{ Yes } & 1 \\
\hline & & & & & 1593 & 0.47 & 0.18 & 0.31 & & & & 1 \\
\hline & & & & \multirow[t]{2}{*}{ PicoMaxx HF (2.5 U) } & 6577 & 0.58 & 1.56 & 1.31 & \multirow[t]{2}{*}{1.98} & \multirow[t]{2}{*}{31.00} & \multirow[t]{2}{*}{ Yes } & 7 \\
\hline & & & & & 17940 & 0.77 & 2.05 & 2.98 & & & & 10 \\
\hline & & & & DNA polymerase & 49926 & 0.91 & 2.27 & 7.38 & \multirow[t]{2}{*}{6.53} & \multirow[t]{2}{*}{102.35} & Yes & 10 \\
\hline & & & & blend (2.5 U) & 38221 & 0.84 & 2.26 & 5.79 & & & & 10 \\
\hline 22 & Swab, & Chelex + & 0.13 & AmpliTaq Gold (2.5 U) & 305 & 0.47 & 0.00 & 0.09 & 0.08 & - & - & 1 \\
\hline & aluminum & Centricon & & & 195 & 0.48 & 0.00 & 0.08 & & & & 1 \\
\hline & can (beer) & & & AmpliTaq Gold (5 U) & 1187 & 0.65 & 1.37 & 0.55 & 0.49 & 5.93 & Yes & 5 \\
\hline & & & & & 864 & 0.55 & 1.12 & 0.43 & & & & 3 \\
\hline & & & & ExTaq Hot Start (2.5 U) & 9416 & 0.81 & 2.28 & 1.89 & 1.82 & 22.18 & Yes & 10 \\
\hline & & & & & 8462 & 0.80 & 2.27 & 1.76 & & & & 10 \\
\hline & & & & PicoMaxx HF (2.5 U) & 7168 & 0.78 & 2.27 & 1.58 & 1.55 & 18.90 & Yes & 10 \\
\hline & & & & & 6712 & 0.85 & 2.28 & 1.53 & & & & 10 \\
\hline & & & & DNA polymerase & 7915 & 0.85 & 2.28 & 1.69 & 1.60 & 19.50 & Yes & 10 \\
\hline & & & & blend (2.5 U) & 6719 & 0.80 & 2.26 & 1.52 & & & & 10 \\
\hline 32 & Moist snuff & Chelex & 0.20 & AmpliTaq Gold (2.5 U) & 1993 & 0.53 & 1.14 & 0.59 & 0.55 & - & - & 4 \\
\hline & & & & & 1505 & 0.50 & 1.08 & 0.51 & & & & 4 \\
\hline & & & & AmpliTaq Gold (5 U) & 7006 & 0.75 & 1.70 & 1.42 & 1.56 & 2.85 & Yes & 8 \\
\hline & & & & & 8897 & 0.73 & 1.83 & 1.71 & & & & 8 \\
\hline & & & & ExTaq Hot Start (2.5 U) & 5808 & 0.60 & 1.44 & 1.18 & 1.18 & 2.16 & Yes & 6 \\
\hline & & & & & 5714 & 0.58 & 1.49 & 1.18 & & & & 6 \\
\hline & & & & PicoMaxx HF (2.5 U) & 4512 & 0.58 & 1.48 & 1.01 & 0.72 & 1.33 & No & 6 \\
\hline & & & & & 1537 & 0.52 & 1.11 & 0.52 & & & & 2 \\
\hline & & & & DNA polymerase & 18235 & 0.84 & 2.10 & 3.04 & 2.74 & 5.02 & Yes & 10 \\
\hline & & & & blend (2.5 U) & 13998 & 0.85 & 2.07 & 2.46 & & & & 10 \\
\hline 42 & Chewing gum & Chelex & 0.19 & AmpliTaq Gold (2.5 U) & 0 & 0.42 & * & 0.05 & 0.05 & - & - & 0 \\
\hline & & & & & 0 & 0.42 & $*$ & 0.05 & & & & 0 \\
\hline & & & & AmpliTaq Gold (5 U) & 0 & 0.42 & * & 0.05 & 0.05 & 1.00 & No & 0 \\
\hline & & & & & 0 & 0.42 & $*$ & 0.05 & & & & 0 \\
\hline & & & & ExTaq Hot Start (2.5 U) & 1825 & 0.56 & 0.85 & 0.50 & 0.16 & 3.17 & Yes & 4 \\
\hline & & & & & 0 & 0.42 & $*$ & 0.05 & & & & 0 \\
\hline & & & & PicoMaxx HF (2.5 U) & 75590 & 0.91 & 2.26 & 10.85 & 10.09 & 201.90 & Yes & 10 \\
\hline & & & & & 64833 & 0.90 & 2.26 & 9.39 & & & & 10 \\
\hline & & & & DNA polymerase & 97738 & 0.93 & 2.28 & 13.85 & 13.08 & 261.68 & Yes & 10 \\
\hline & & & & blend (2.5 U) & 86671 & 0.94 & 2.28 & 12.36 & & & & 10 \\
\hline
\end{tabular}

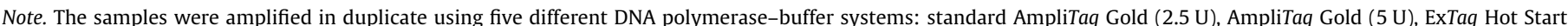

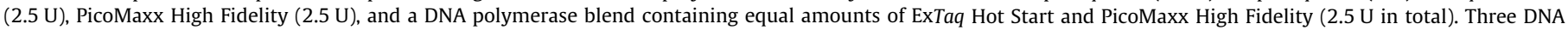

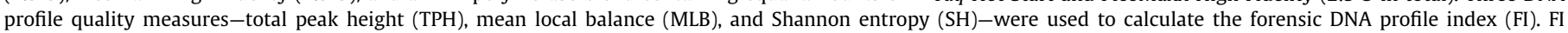

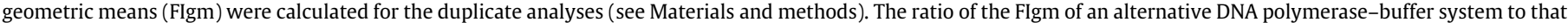

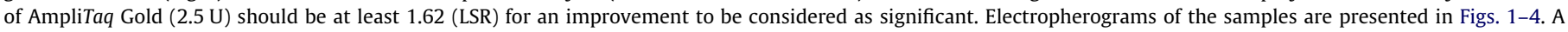
complete list of results for all analyzed samples is provided in Table S2 of Supplementary material.

a Negative/blank DNA profiles were given an MLB value of 0.42 , the SH notation “*” (not possible to calculate SH for negative profiles), and an FI value of 0.05, as described in Ref. [6].

by mutations [11]. In the current study, sample type had a notable impact on the performance of the two tested alternative DNA polymerases. Moreover, one of the systems performed well in the presence of samples that inactivated the other system; that is, the polymerases showed complementary inhibitor-resisting properties. Positive complementary effects were evident in the blend given that it performed as well as, or better than, the best performing DNA polymerases for all samples of all types, notwithstanding that only half of the amount of each polymerase was added compared with the single DNA polymerase reactions. Thus, the blend enabled DNA amplification in the presence of a broader spectrum of disturbing substances compared with each individual system (Figs. 1-4, Table 2, and Table S2).
The complementary effects of the DNA polymerase-buffer systems may be explained by the mechanism(s) of the inhibitor(s) present. Most characterized PCR inhibitors affect the DNA polymerase either directly by blocking the active site or inducing degradation or indirectly by affecting the reaction environment [25]. Certain inhibitory molecules may be able to block the active sites of some DNA polymerases but not others, leaving these polymerases unaffected. This may be the case for the complementary DNA polymerases used here. Furthermore, DNA polymerases may have different abilities to retain activity in different ion concentration ranges [8]. Humic and fulvic acids in soil are examples of inhibitors with DNA polymerase binding properties [26], lactoferrin and heme in blood release iron ions [27] disturbing the ion 
balance, and phytic acid in feces chelates magnesium ions [28], a vital cofactor for DNA polymerases.

In true crime scene stains, the inhibitor content is complex and generally unknown. When lacking the information needed to choose the most appropriate PCR chemistry for the sample in question, a DNA polymerase blend with complementary DNA polymerases may be beneficial. Some information on the inhibitory effects may be gained from studying the nature of the samples. Cigarettes and moist snuff are tobacco products but still seem to have quite different PCR-inhibitory effects judging from the discrepancies in amplification success using either ExTaq Hot Start or PicoMaxx High Fidelity (Figs. 1 and 3). For cigarettes, the paper around the filter is used for DNA extraction. The paper is made from cellulose, and wood components are known PCR inhibitors [29]. The combustion of tobacco releases thousands of chemical compounds possibly affecting PCR such as formaldehydes [30] and phenols [10]. Moist snuff contains pasteurized tobacco, sodium chloride, sodium carbonate, and propylene glycol. Salts releasing $\mathrm{Na}^{+}$ions could affect PCR [26,31]. Glycols could provide a favorable environment for amplification [32,33], but if the concentration is too high they can inhibit the PCR [31]. Thus, ExTaq Hot Start may be better at resisting raw tobacco and PicoMaxx High Fidelity may be better at resisting its various combustion products.

For moist snuff, doubling the amount of AmpliTaq Gold produced substantial improvements, showing that simply adding more DNA polymerase may help to overcome inhibition in some cases [34]. The good performance from increasing the amount of AmpliTaq Gold coincided with positive effects using ExTaq Hot Start. Conversely, the relatively poor performance of ExTaq Hot Start on cigarette butts and chewing gum coincided with minor positive effects using increased amounts of AmpliTaq Gold. Elevating the amount of AmpliTaq Gold to 7.5 and $10 \mathrm{U}$ had no effect for 3 cigarette butt and chewing gum samples showing significant inhibition (Table S2, samples 4, 16, and 38). Together, these results indicate that AmpliTaq Gold and ExTaq Hot Start have similar inhibitor tolerance properties; that is, they are affected by the same substances, although ExTaq Hot Start is
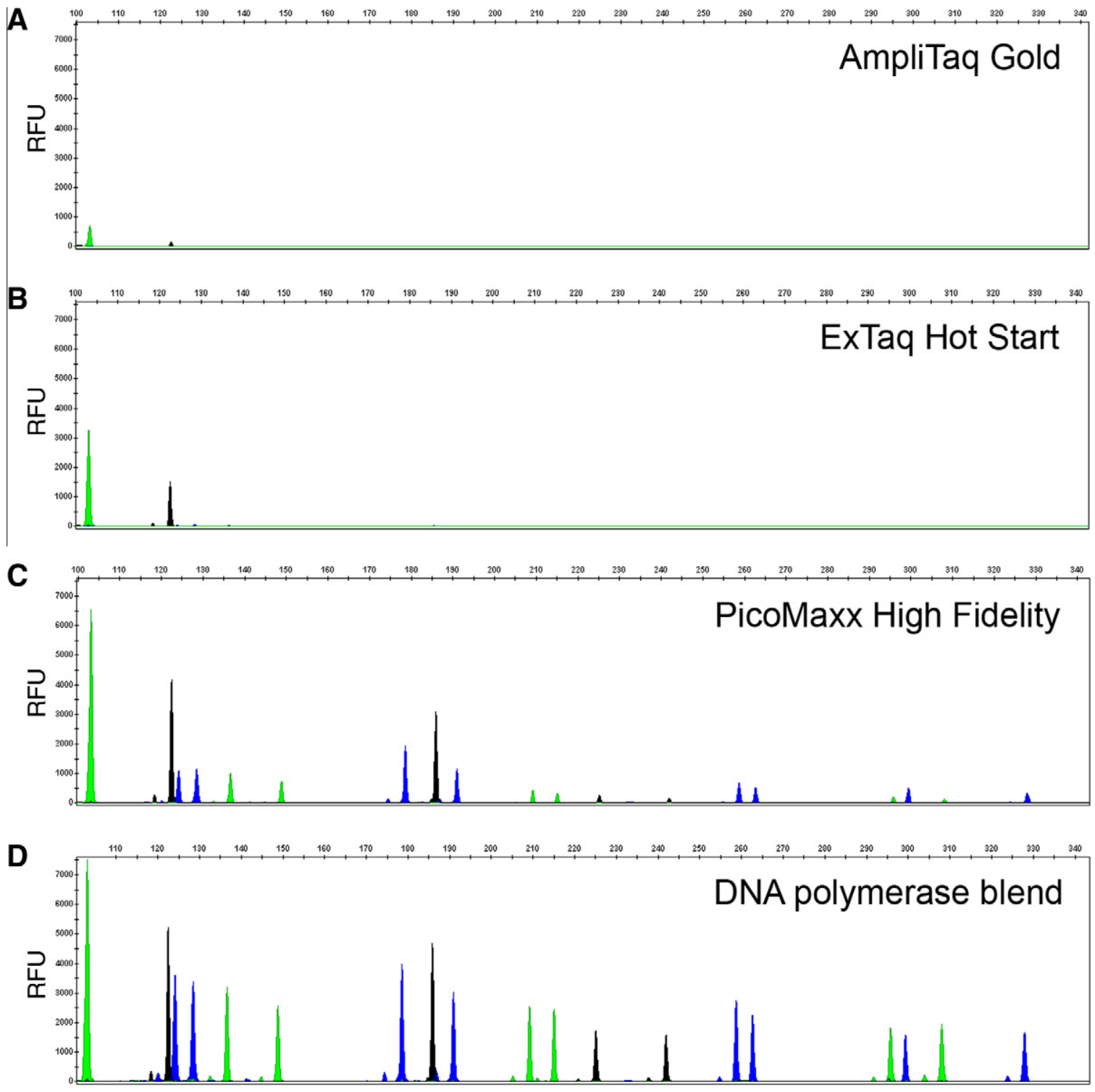

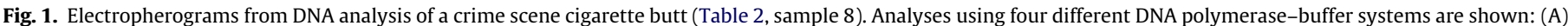

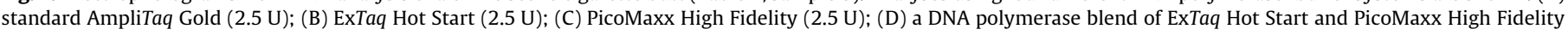
(2.5 $\mathrm{U}$ in total). The allelic peak heights are given in relative fluorescence units. 
affected to a lesser extent. PicoMaxx High Fidelity shows distinct properties, being highly affected by moist snuff but not by cigarette butts and chewing gum.

The superior performance of the DNA polymerase blend compared with single DNA polymerases can be explained partly by complementary effects of the included DNA polymerase buffer systems. Two conditions need to be fulfilled if complementary effects are to be the only explanation. First, for a certain sample, the blend should not be able to produce DNA profiles of significantly higher quality compared with either of the systems used separately. The maximum performance of the blend would be equal to that of the best performing system. Second, for samples that generate negative DNA profiles using one of the DNA polymerase-buffer systems and complete DNA profiles using the other system as well as the blend, half the amount $(1.25 \mathrm{U})$ of the best performing DNA polymerase should generate profiles of similar quality as the blend. This means that, because the blend is made up of $1.25 \mathrm{U}$ of each polymerase, the only active part in the blend would be the DNA polymerase that retains activity when used separately.
The first statement is challenged by the fact that for six especially complicated samples, the blend generated DNA profiles of significantly higher quality compared with both ExTaq Hot Start and PicoMaxx High Fidelity used separately (see Figs. 1 and 3, Table 2, and Table S2, samples $8,13,16,25,32$, and 40). This could not be a complementary effect but rather indicates synergy. To test the second statement, four samples that generated negative/nearly negative DNA profiles using ExTaq Hot Start and complete DNA profiles using either 2.5 U PicoMaxx High Fidelity or the blend were analyzed using 1.25 $\mathrm{U}$ of PicoMaxx High Fidelity. The blend generated higher FIgm values compared with $1.25 \mathrm{U}$ PicoMaxx High Fidelity for all tested samples, indicating that ExTaq Hot Start, although inactive when used separately, retained some activity in the blend (FIgm ratios between 1.40 and 2.10) (Table S2, samples 4, 14,41 , and 42).

Synergy between DNA polymerase-buffer systems may have various explanations. One of the DNA polymerases may perform better in the initial cycles, creating a critical mass of product that the other polymerase can use as template to produce large
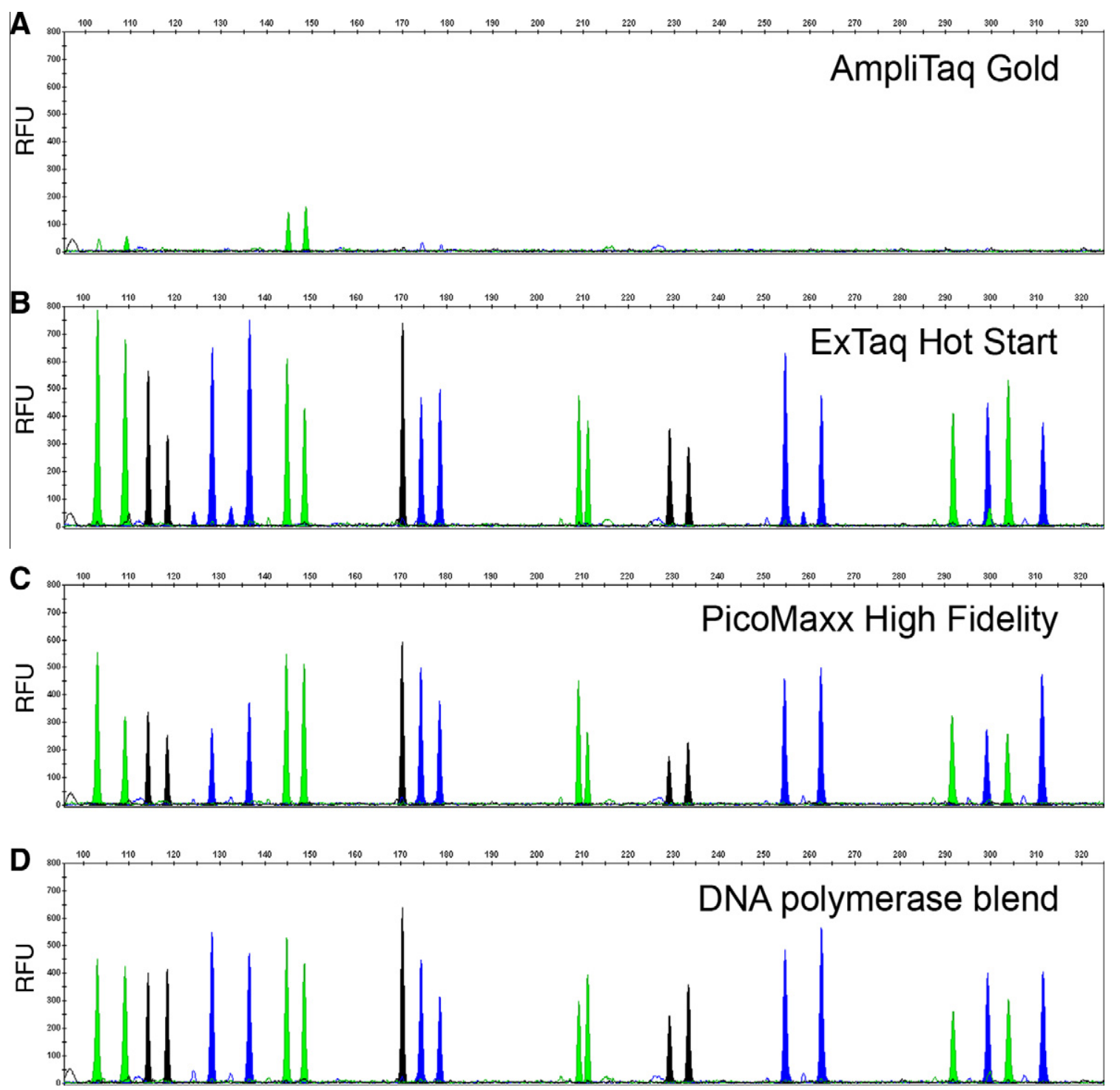

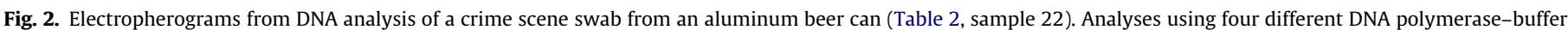

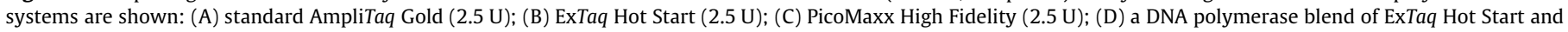
PicoMaxx High Fidelity ( $2.5 \mathrm{U}$ in total). The allelic peak heights are given in relative fluorescence units. 
amounts of amplicons. Buffer components may also be important in the sense that compounds present in the buffer system of one DNA polymerase may be beneficial for the activity of the other polymerase in the blend. The presence or absence of PCR facilitators is a well-known factor determining the amplification efficiency of DNA polymerases in general [35], and several different compounds have been used to counteract PCR inhibition [25]. Examples of PCR facilitators that have been shown to increase inhibitor tolerance include proteins such as BSA $[14,26]$ and nonionic detergents such as Tween 20 and Triton X-100 [33,36]. BSA is included in the AmpFlSTR reaction buffer used routinely with the AmpFlSTR SGM Plus kit (AmpFISTR SGM Plus PCR Amplification Kit user's manual). To provide similar conditions for all tested DNA polymerases, BSA content was normalized in the reaction mixes of the alternative DNA polymerases. The content of the supplied PCR buffers is partly proprietary, implying that other PCR facilitators may be present. The PicoMaxx High Fidelity system contains a polymerase enhancement factor purified from
Pyrococcus furiosus $[19,20]$ that may also stimulate ExTaq Hot Start.

Modifying the PCR chemistry by employing a blend of inhibitortolerant DNA polymerase-buffer systems significantly increased the quality of DNA profiles from crime scene samples showing PCR inhibition compared with standard AmpliTaq Gold. The blend performed better than the included alternative DNA polymerases used separately and also performed better than AmpliTaq Gold in increased amounts. The two DNA polymerase-buffer systems, ExTaq Hot Start and PicoMaxx High Fidelity, complemented each other given that one stayed active in an environment that inactivated the other. We also found evidence of synergy given that the performance of the two DNA polymerase-buffer systems used together was better than what would be expected from the results of each system used separately. To our knowledge, this is the first time that a DNA polymerase-buffer system blend has been designed to increase PCR inhibitor tolerance. The general approach may be applied in any scientific field using diagnostic PCR analysis.
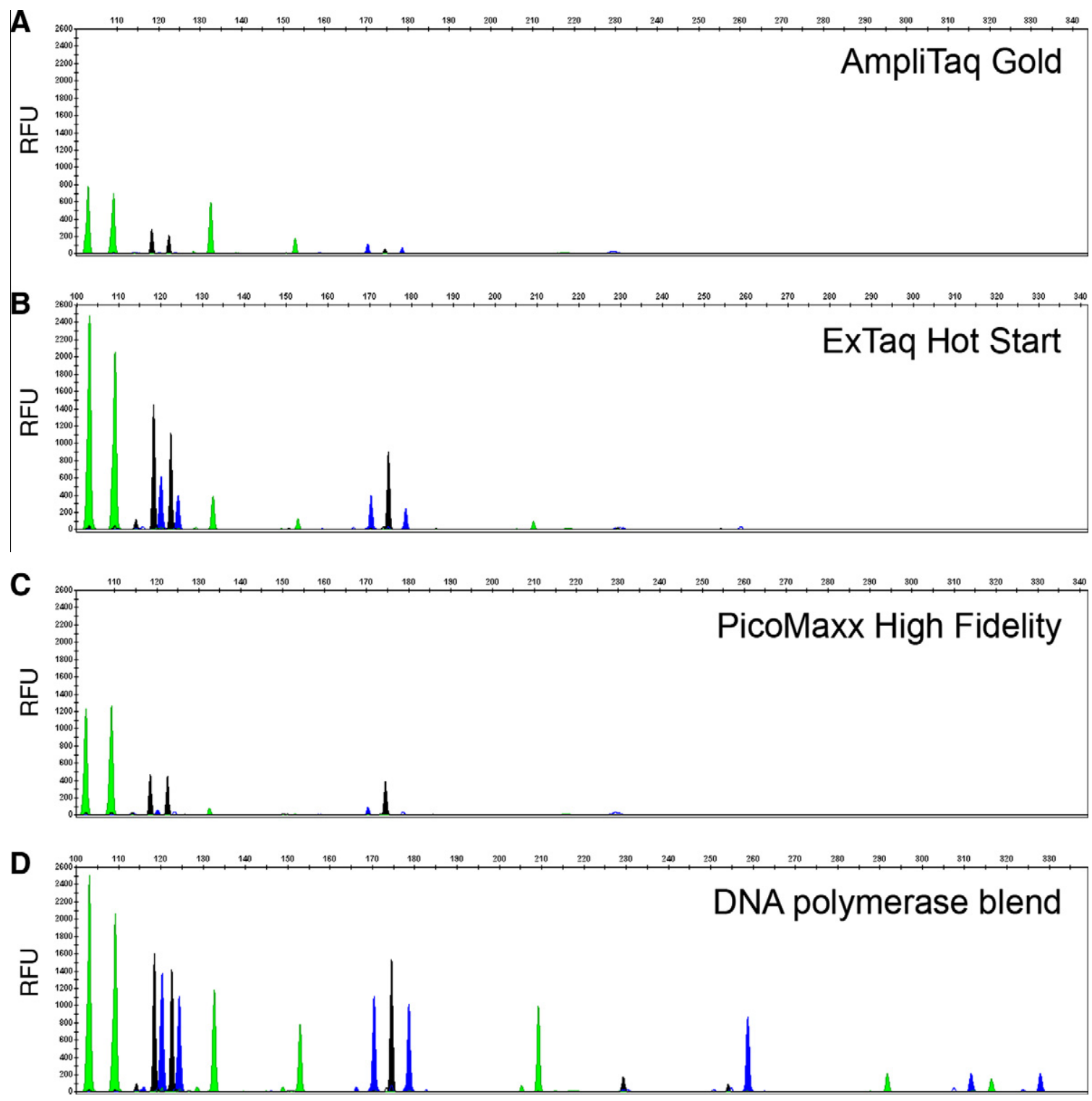

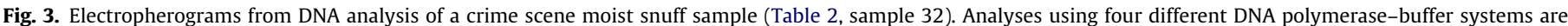

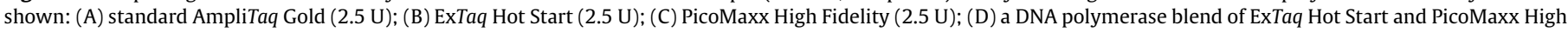
Fidelity (2.5 $\mathrm{U}$ in total). The allelic peak heights are given in relative fluorescence units. 

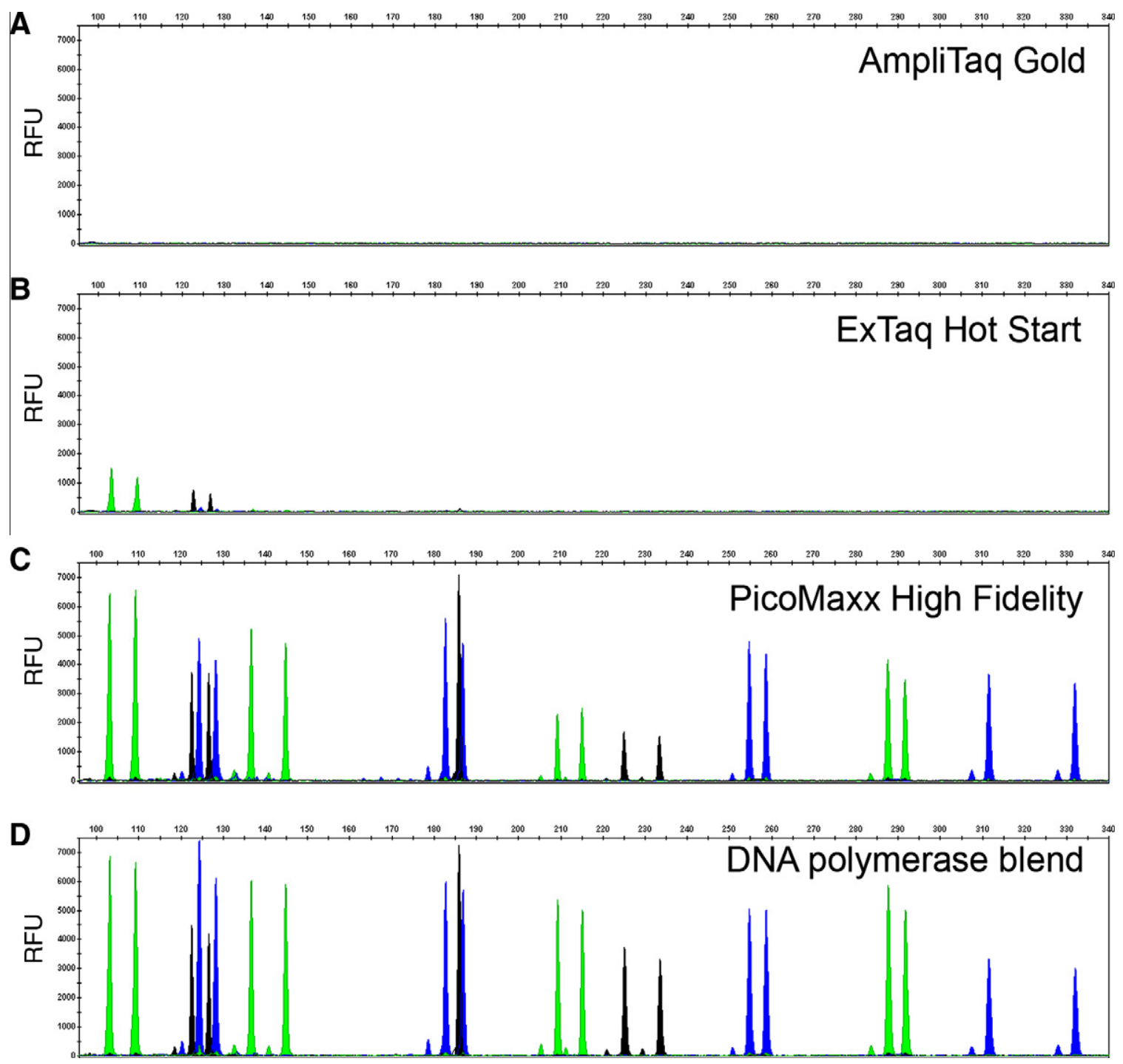

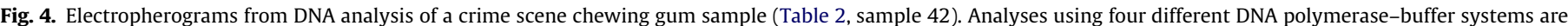

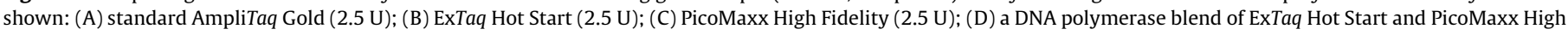
Fidelity (2.5 $\mathrm{U}$ in total). The allelic peak heights are given in relative fluorescence units.

\section{Acknowledgments}

The authors are grateful to Linda Albinsson and the DNA typing group at the Swedish National Laboratory of Forensic Science (SKL) for technical support. This work was financially supported by SKL. The work of Peter Rådström was partially supported by the Swedish Research Council for Environment, Agricultural Sciences, and Spatial Planning.

\section{Appendix A. Supplementary data}

Supplementary data associated with this article can be found, in the online version, at doi:10.1016/j.ab.2010.06.028.

\section{References}

[1] R.K. Saiki, D.H. Gelfand, S. Stoffel, S.J. Scharf, R. Higuchi, G.T. Horn, K.B. Mullis, H.A. Erlich, Primer-directed enzymatic amplification of DNA with a thermostable DNA polymerase, Science 239 (1988) 487-491.

[2] I.G. Wilson, Inhibition and facilitation of nucleic acid amplification, Appl. Environ. Microbiol. 63 (1997) 3741-3751.

[3] G.G. Shutler, P. Gagnon, G. Verret, H. Kalyn, S. Korkosh, E. Johnston, J. Halverson, Removal of a PCR inhibitor and resolution of DNA STR types in mixed human-canine stains from a five year old case, J. Forensic Sci. 44 (1999) 623-626.

[4] M.T. Bourke, C.A. Scherczinger, C. Ladd, H.C. Lee, NaOH treatment to neutralize inhibitors of Taq polymerase, J. Forensic Sci. 44 (1999) 1046-1050.

[5] A. Akane, H. Shiono, K. Matsubara, H. Nakamura, M. Hasegawa, M. Kagawa, Purification of forensic specimens for the polymerase chain reaction (PCR) analysis, J. Forensic Sci. 38 (1993) 691-701.

[6] J. Hedman, A. Nordgaard, B. Rasmusson, R. Ansell, P. Rådström, Improved forensic DNA analysis through the use of alternative DNA polymerases and statistical modeling of DNA profiles, BioTechniques 47 (2009) 951958.

[7] K.D. Eilert, D.R. Foran, Polymerase resistance to polymerase chain reaction inhibitors in bone, J. Forensic Sci. 54 (2009) 1001-1008.

[8] W. Abu Al-Soud, P. Rådström, Capacity of nine thermostable DNA polymerases to mediate DNA amplification in the presence of PCR-inhibiting samples, Appl. Environ. Microbiol. 64 (1998) 3748-3753.

[9] L. Belec, J. Authier, M.C. Eliezer-Vanerot, C. Piedouillet, A.S. Mohamed, R.K. Gherardi, Myoglobin as a polymerase chain reaction (PCR) inhibitor: a limitation for PCR from skeletal muscle tissue avoided by the use of Thermus thermophilus polymerase, Muscle Nerve 21 (1998) 1064-1067.

[10] H.L. Katcher, I. Schwartz, A distinctive property of Tth DNA polymerase: enzymatic amplification in the presence of phenol, BioTechniques 16 (1994) 84-92.

[11] M.B. Kermekchiev, L.I. Kirilova, E.E. Vail, W.M. Barnes, Mutants of Taq DNA polymerase resistant to PCR inhibitors allow DNA amplification from whole blood and crude soil samples, Nucleic Acids Res. 37 (2009) e40.

[12] P.S. Walsh, D.A. Metzger, R. Higuchi, Chelex 100 as a medium for simple extraction of DNA for PCR-based typing from forensic material, BioTechniques 10 (1991) 506-513. 
[13] M.N. Hochmeister, B. Budowle, J. Jung, U.V. Borer, C.T. Comey, R. Dirnhofer, PCR-based typing of DNA extracted from cigarette butts, Intl. J. Legal Med. 104 (1991) 229-233.

[14] M.N. Hochmeister, B. Budowle, U.V. Borer, U. Eggmann, C.T. Comey, R. Dirnhofer, Typing of deoxyribonucleic acid (DNA) extracted from compact bone from human remains, J. Forensic Sci. 36 (1991) 1649-1661.

[15] E.R. Scalice, D.J. Sharkey, K.G. Christy Jr., T.W. Esders, J.L. Daiss, Thermostable polymerase specific antibody-containing DNA amplification composition and kit, U.S. patent 5587287 (1996).

[16] E.R. Scalice, D.J. Sharkey, K.G. Christy Jr., T.W. Esders, J.L. Daiss, DNA amplification with thermostable DNA polymerase and polymerase inhibiting antibody, U.S. patent 5338671 (1994).

[17] E.J. Mathur, Purified thermostable Pyrococcus furiosus DNA polymerase I, U.S. patent 6489150 (2002).

[18] J.A. Sorge, R.L. Mullinax, Polymerase compositions and uses thereof, U.S. patent 5556772 (1996).

[19] H. Hogrefe, Polymerase enhancing factor (PEF) extracts, PEF protein complexes, isolated PEF proteins, and methods for purifying and identifying same, U.S. patent 6183997 (2001).

[20] H. Hogrefe, Polymerase enhancing factor (PEF) extracts, PEF protein complexes, isolated PEF proteins, and methods for purifying and identifying same, U.S. patent 6444428 (2002).

[21] J. Hedman, R. Ansell, A. Nordgaard, A ranking index for quality assessment of forensic DNA profiles, manuscript in preparation.

[22] W.M. Barnes, PCR amplification of up to 35-kb DNA with high fidelity and high yield from $\lambda$ bacteriophage templates, Proc. Natl. Acad. Sci. USA 91 (1994) 2216-2220.

[23] S. Cheng, C. Fockler, W.M. Barnes, R. Higuchi, Effective amplification of long targets from cloned inserts and human genomic DNA, Proc. Natl. Acad. Sci. USA 91 (1994) 5695-5699.

[24] W. M. Barnes, Thermostable DNA polymerase with enhanced thermostability and enhanced length and efficiency of primer extension, U.S. patent 5436149 (1995)
[25] P. Rådström, R. Knutsson, P. Wolffs, M. Lövenklev, C. Löfström, Pre-PCR processing: strategies to generate PCR-compatible samples, Mol. Biotechnol. 26 (2004) 133-146.

[26] C.A. Kreader, Relief of amplification inhibition in PCR with bovine serum albumin or T4 gene 32 protein, Appl. Environ. Microbiol. 62 (1996) 1102-1106.

[27] W. Abu Al-Soud, P. Rådström, Purification and characterization of PCRinhibitory components in blood cells, J. Clin. Microbiol. 39 (2001) 485-493.

[28] C.G. Thornton, S. Passen, Inhibition of PCR amplification by phytic acid, and treatment of bovine fecal specimens with phytase to reduce inhibition, J. Microbiol. Methods 59 (2004) 43-52.

[29] A.B. Lee, T.A. Cooper, Improved direct PCR screen for bacterial colonies: wooden toothpicks inhibit PCR amplification, BioTechniques 18 (1995) 225226.

[30] D.W. Johnson, N.J. Pieniazek, D.W. Griffin, L. Misener, J.B. Rose, Development of a PCR protocol for sensitive detection of Cryptosporidium oocysts in water samples, Appl. Environ. Microbiol. 61 (1995) 3849-3855.

[31] L. Rossen, P. Norskov, K. Holmstrom, O.F. Rasmussen, Inhibition of PCR by components of food samples, microbial diagnostic assays, and DNA-extraction solutions, Intl. J. Food Microbiol. 17 (1992) 37-45.

[32] T. Demeke, R.P. Adams, The effects of plant polysaccharides and buffer additives on PCR, BioTechniques 12 (1992) 332-334.

[33] W. Abu Al-Soud, P. Rådström, Effects of amplification facilitators on diagnostic PCR in the presence of blood, feces, and meat, J. Clin. Microbiol. 38 (2000) 4463-4470.

[34] D. Sutlovic, M. Definis Gojanovic, S. Andelinovic, D. Gugic, D. Primorac, Taq polymerase reverses inhibition of quantitative real time polymerase chain reaction by humic acid, Croat. Med. J. 46 (2005) 556-562.

[35] P. Wolffs, H. Grage, O. Hagberg, P. Rådström, Impact of DNA polymerases and their buffer systems on quantitative real-time PCR, J. Clin. Microbiol. 42 (2004) 408-411.

[36] M.C. Simon, D.I. Gray, N. Cook, DNA extraction and PCR methods for the detection of Listeria monocytogenes in cold-smoked salmon, Appl. Environ. Microbiol. 62 (1996) 822-824. 